\title{
Legacies of Violence
}



http://ebookcentral.proquest.com/lib/jcu/detail.action?doclD=4586011. 


\section{LEGACIES OF ViOlence \\ Rendering the Unspeakable Past}

in Modern Australia

$\infty$

Edited by

Robert Mason

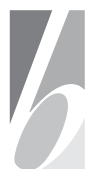

berghahn

NEW YORK・ OXFORD

www.berghahnbooks.com 


\author{
Published in 2017 by \\ Berghahn Books \\ www.berghahnbooks.com \\ (C) 2017 Robert Mason
}

\begin{abstract}
All rights reserved. Except for the quotation of short passages for the purposes of criticism and review, no part of this book may be reproduced in any form or by any means, electronic or mechanical, including photocopying, recording, or any information storage and retrieval system now known or to be invented, without written permission of the publisher.
\end{abstract}

\title{
Library of Congress Cataloging-in-Publication Data
}

Names: Mason, Robert, 1981- editor of compilation.

Title: Legacies of violence : rendering the unspeakable past in modern Australia / edited by Robert Mason.

Description: New York : Berghahn Books, 2017. | Includes bibliographical references and index.

Identifiers: LCCN 2016053207 (print) | LCCN 2016054587 (ebook) | ISBN 9781785334368 (hardback : alkaline paper) | ISBN 9781785334375 (e-book)

Subjects: LCSH: Violence-Australia-History. | Violence-Australia-Case studies. | Marginality, Social-Australia-History. | Australia-Social conditions. | Australia-Race relations. | Australia-Ethnic relations.

Classification: LCC HN850.Z9 V55 2017 (print) | LCC HN850.Z9 (ebook) | DDC 303.60994-dc23

LC record available at https://lccn.loc.gov/2016053207

\section{British Library Cataloguing in Publication Data}

A catalogue record for this book is available from the British Library

ISBN 978-1-78533-436-8 hardback

ISBN 978-1-78533-437-5 ebook 


\section{Contents}

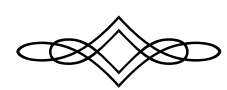

List of Illustrations vii

Introduction: Rendering the Legacies of the Past 1 Robert Mason

1. The Politics of State-Sanctioned Violence in Australia:

Racialized Constructions of Nation $\quad 11$

Linda Briskman

\section{Part I Hidden Violence}

2. Uncovering the Shameful: Sexual Violence on an Australian Colonial Frontier

Libby Connors

3. Fighting for Dignity: Migrant Identities in the Workplaces of Northern Australia

Robert Mason

4. The Family Trust: On Assimilation, Migration and Concealing Ambivalent Identities

Ruth Longdin

5. Legacies of the Uyghur Homeland and Uyghur-Australians Anna Hayes

\section{Part II Intimate Violence}

6. The Greek Civil War, Child Removal and Traumatic Pasts in Australia

Joy Damousi 
7. From Hell to Hope: Postwar Jewish Holocaust Survivor Migration

Suzanne Rutland

8. HIV/AIDS, Loss and the Australian Gay Community

Robert Reynolds and Shirleene Robinson

Part III Sanctioned Violence

9. The RSL and Post-First World War Returned Soldier Violence in Australia

Martin Crotty

10. Service Personnel: Australian Experiences of Interculturality and Violence in British India

Richard Gehrmann

11. Race and Ethnicity in Sex Crimes Trials from 1950s Australia Andy Kaladelfos and Lisa Featherstone

12. The Violence of Exclusion: Australia's Migration Zone Excision and the State of Exception

Farida Fozdar

Index 


\section{Illustrations}

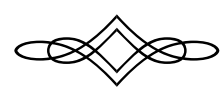

\section{FIGURES}

Figure 5.1 Changing Ethnic Ratios in Xinjiang since PRC annexation in $1949(\%)$.

Figure 5.2 Location of Xinjiang Uyghur Autonomous Region.

\section{TABLES}

Table 5.1 Key subtext of posts.

Table 5.2 Key subtexts of response posts. 

http://ebookcentral.proquest.com/lib/jcu/detail.action?doclD=4586011. 


\section{Introduction}

\section{Rendering the Legacies of the Past}

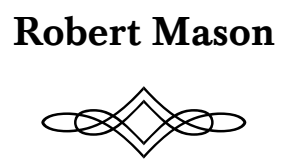

Australia's sense of nationhood has been born from its experience of violence. This collection investigates the legacies of violence wrought by warfare, indigenous dispossession, migration and prejudice. Contributors focus on the way in which the memories and experiences of violence have created tangible and emotional connections that bind Australians to events and debates globally. Chapters question how these connections have been experienced within Australia, probing the nature of empathy, isolation and Australians' imagined place in the world through the country's colonial and modern history. Engaging with these issues is fundamental to a fuller understanding of how past experiences of violence continue to shape Australia today.

In common with many other former white-settler societies, modern Australia has been formed by dispossession, war and forced migration. There are patterns and commonalities in how the legacies of these various forms of violence have been experienced. The collection recognizes the authority generally accorded to white experiences of violence, whether on the frontier, in warfare or in domestic spaces. For this reason, it questions how violence is experienced by those perceived to be at the periphery of society - whether migrants, Indigenous Australians or other vulnerable communities. The collection repositions these experiences at the centre of Australia's connectivity with locales and debates across the globe.

Interest in the legacies of the past has increased enormously in the past twenty years throughout the Global North. Museums, heritage precincts, 
public inquiries and reconciliation commissions have variously dwelt on the power of the past to influence events in the present. Australia has not been isolated from this, with public inquiries into institutional child abuse, the Stolen Generation of Indigenous Australians and child migration schemes variously dominating public debate. Tourists flock to sites of colonial violence such as the Port Arthur site in Tasmania, although other sites of massacre remain detached from mainstream awareness. Despite the interest in dark tourism and the country's colonial past, there is little critical reflection on how sites and instances of violence might connect. Nor has there been a systematic critical reflection on how the country's violent past has influenced Australia's sense of connectivity with the rest of the world. This collection challenges accepted interpretations of the national narrative and interrogates the legacies of violence in modern Australia.

The collection's title expresses how the past is variously portrayed and positioned to support contemporary arguments. Interpreted differently, the title also suggests an exploration into how those pasts continue to resonate today and what lessons can be drawn from the country's experience of violence. Undergraduate students often respond enthusiastically to questions about 'why history matters' by reflecting on the need to prevent the mistakes of the past repeating themselves. However, such responses frequently frame violence as an occasional aberration that can be safely located and compartmentalized in the past. The contributors in this collection instead investigate parallels and connections across diverse case studies that go beyond specific times, places or groups. Their work draws together history and anthropology with social justice to create a new understanding of historical justice and social memories in Australia. In so doing, the collection interrogates how and why violence is remembered, forgotten or silenced, and the implications of this for a critical reflection on modern Australia.

The past has occupied a polemical position in Australian politics for a number of decades. This was clearest during the so-called 'History Wars', in which conservative commentators attacked a number of prominent academics and accused them of overstating the violence that occurred during the British settlement of Australia. The then prime minister, John Howard, attacked those who suggested a 'black armband' version of Australian history that suggested the nation's founding narratives were shameful. Instead, he supported an emphasis on British heritage and a triumphal interpretation of Europeans' presence on the continent. The debates were prolonged and highly emotive, but they demonstrated the power of history to influence contemporary debate, and the extent to which the present remains inextricably entangled in the past. 
The debates surrounding the History Wars were not isolated examples, although they drew particularly on Australia's relationship to its colonial and indigenous pasts. The rapid changes to Australian society in the past fifty years have given prominence to debates regarding the nation's past and their role in defining core values for the country's present. This is most noticeable in recent debates surrounding the centenary of the First World War and the Gallipoli campaign. Historians continue to contribute actively to public debate regarding Australia's particular experience of violence, gender and race in contemporary society. The commemoration of Gallipoli is used as a tool to reach beyond Australia and build connections across cultures. However, comparable discussion using the anniversary of James Cook's landing as a tool for reflection on violence remains fraught with political bias and is almost wholly unconnected to broader social awareness on the legacies of global imperialism.

Major commemorations necessarily activate memories and prompt a degree of reflection, but what of the everyday presence of the past? Australia's burgeoning interest is part of a global growth in interest regarding historical justice and memory. Scholars have focused on the role of history in conflict resolution during protracted conflicts, or of social attitudes to unresolved historical injustices. Truth and reconciliation commissions are now widely used to give voices to the victims of violence as part of a transition to more inclusive societies. Historians have sought to use history to cast light on contemporary immigration and refugee policy, although asylum seekers' voices remain largely unheard. What of those for whom there is little broad social recognition of injustice, or for whom the injustice no longer appears relevant. This collection seeks to draw together examples from the recent and more distant past to open spaces for reflection on countries' shared experience of violence.

The volume is divided into three parts, structured around three ways in which violence can be positioned: hidden violence, intimate violence and sanctioned violence. Each one draws on chronologically linear examples of violence from throughout Australia's recent history, ending with an example from contemporary Australia. Contributors have consciously emphasized the personal testimonies and voices that are at the heart of their chapters. In this way, the collection resists the notion of maintaining a critical distance from a problem, and instead encourages the reader's entanglement in the connections between past and present. The chapters encourage the reader to respond to the emotionality of loss and the affective power of testimony to bind the reader into the research space.

Each chapter explores a discrete case study, but a number of themes recur throughout the volume. Whiteness is the first powerful theme that 
integrates the whole collection. Studies in whiteness and race have long demonstrated the former's powerful influence in the formation of a national narrative and individual sense of self. This idea of Australia draws on a highly masculinized, militarized and overtly heterosexual presence in the landscape. From its colonial beginnings to the traumas of the twentieth century, whiteness has been central to debates regarding the need to protect Australia against external threats from Asia. It has also been a pervasive influence in the positioning of supposed non-white attributes as a form of moral contagion, leading to non-whites being criminalized, excluded and physically distanced from the majority of residents.

Chapters also centre on continuities and changes regarding the state's influence in society. This is closely tied to the evolution of the colonial and imperial project in Australia, and to the transformation of government from its management of a penal colony to a white dominion, and eventual multicultural state. A number of contributors evaluate the state's power to protect and to deny protection to residents and others, defining the rights of humans within its borders and beyond. The state's role in forming the language of governance and laws has also been central to the enforcement of power across boundaries of gender, sexuality and race. In examining this, the collection explores what it means to resist this attempt to control and dehumanize.

The third theme that integrates the various sections of the book is the transnational context of violence. The collection is predicated on a desire to identify the patterns across legacies of the past in Australia, but does so in the recognition of global movement of people, ideas and capital. Although much of Australia's history is particular to the continent, its recent history can be placed in a series of global trends, whether in settler societies, imperial endeavours or the management of cultural diversity. More specifically, Australia's policies and practices of control can be understood in a transnational pattern of discourse relating to the enactment of island incarcerations or the displacement and exclusion from lands of indigenous people, and the resonance of these acts in society.

A final theme relates to the ability to speak and bear witness. This explores the need to give voice to those whose life experiences have been silenced, and why experiences might be considered unspeakable. The state and society's ability to deny testimonies, histories or experiences connects strongly with the notions of silencing through erasure, fear and the presence of taboo subjects. Such themes are recurrent throughout much of modern scholarship and have affected the discursive formulae available to vulnerable migrants, Indigenous Australians, homosexuals, women and others. Constrained in the language available to them, this silencing 
risked negating key aspects of identity, as the self was denied, attacked or fragmented. The impact across generations and the body politic is at the heart of the collection.

More broadly, the volume engages with the cultural meaning of violence in Australia over time and historical context. Violence offers ways of understanding the broader historical moment, revealing social relations and norms that are otherwise hidden or obscured from the historical record. Appreciating the evolution of violence within a society over time enables scholars to move beyond a particular moment to see patterns in society's sense of itself and its relations with others.

Violence is not simply a cultural phenomenon. It is experienced in a real and visceral manner by victims, but also by perpetrators and those who (willingly, consciously or otherwise) bear witness to the act. Together, all three groups give meaning to specific acts of violence. They determine public debate, the historical record and the legacy of the violence in social memories. The categories also help to understand the trajectories of violence over time as the violent incidents are spoken about, performed, embodied and inscribed into landscapes. Just as the violence changes those to whom it occurs, it can have a transformative effect on those who continue to bear witness or feel connection to the violence for years to come. Such connections need not be continuous, and the changing meaning of violence might cause an event to reappear and resonate in public consciousness decades after its occurrence.

Violence can give authority to those who wield it, and to those who experience it. Relationships can be transformed as former perpetrators become victims, or as victims are reimagined in their turn. One way to change the perception of past violence can be through public 'truth telling' as a means to mend social relations. Acts of witnessing, and its role in the healing process, can extend beyond having witnessed the actual act to witnessing the pain of speaking about violence. In this sense, although violence is not always a singular occurrence but can reoccur, so too can healing. Survivors' voices demand recognition at the time of the act, but also through history. As Klaus Neumann and Janna Thomson rightly note, ${ }^{1}$ such remembrance affirms victims and confirms their positionality. In this manner, remembering is itself both an act of justice and a requirement of justice. This requirement lies at the heart of the collection's chapters.

Linda Briskman's chapter sets the context for the collection's three parts. In her discussion about the experiences of both Indigenous Australians and asylum seekers, she asks why so many of the injustices imposed on First Peoples are also experienced by the country's most recent arrivals. She identifies the convergence of fear, racism and exceptionalism, all of which 
structure the lives of the marginalized. Her analysis centres on three themes that connect the banishment of Indigenous Australians and asylum seekers: namely, sites of exclusion, denial of rights and attacks on their identity. Together these three themes are duplicated throughout the chapters within the collection, and for this reason her work acts as an extended, scholarly introduction to the volume as a whole.

Libby Connors provides the first chapter in the part on 'Hidden Violence', which explores sites and expressions of violence that have not been visible for reasons of fractured evidence or the lack of a common language of expression. Connors' chapter investigates the nature of evidence in historical contexts of trauma, violence and unequal power relationships. Her work draws directly on the debates of the History Wars to ask how hidden violence might be expressed and explored. Her focus on the colonial frontier across generations situates questions of genocide in the global context of colonialism, race and gender. The chapter's particular focus on the frontier 'cult of domesticity' reveals that attempts to control, displace or erase the Aboriginal presence were connected to an imposition of patriarchal order in the home space. Her analysis reveals the early racialization of crime and gender, which was to continue throughout Australian history, and that is later explored by other authors in the collection.

Robert Mason's chapter continues the focus on non-urban Australia in its analysis of non-English-speaking migrants in the country's north. The chapter draws on Spanish-language archival materials, highlighting the more general focus on English records that obscures counternarratives to the development of Anglo-Australia. The chapter investigates the nexus between migration, class and economic development to explore how migrants experience whiteness in the workplace. Mason is particularly interested in the global connections that informed the migrants' active resistance to corporate businesses in the sugar-cane fields of tropical Australia. The workers' demand for dignity was part of a transnational challenge to racial and class hierarchies, which nonetheless informed the development of labour rights in Australia. Mason uses the political and industrial identities to explore how past experiences are remembered, transformed and enacted in Australia.

Ruth Longdin's chapter explores the violence caused by the silencing of narratives of prejudice and discrimination. Her piece begins with the serendipitous discovery of a collection of letters that had been consigned to a rubbish dump and forgotten. Her chapter uses these letters to trace a family biography across multiple continents and decades, investigating questions of anti-Semitism and the shifting legacy of chance mistakes. It reveals the strategies of concealment used to attain a sense of social belonging. Like a number of contributions, this chapter questions how silences migrate across 
time and place, and are experienced according to gender, class and religion. Longdin's case study is an important reminder that migration to Australia was only one phase in a search for security as families dispersed throughout the world. Although Australia allowed a degree of security through the concealment of former experiences, the past nonetheless intruded unexpectedly, and challenged attempts to silence it.

The final chapter in Part I continues the examination of mobile populations with a focus on Chinese exiles in Australia. Anna Hayes uses the contemporary case study of the Uyghur community to probe how questions of disputed histories and injustice overseas influence Australians. In common with Mason in his chapter, she explores how overseas disputes connect Australians literally and emotively with groups elsewhere. Hayes analyses internet commentary regarding a prominent Uyghur activist to explore the connections between events in China and Australians' sense of human rights. She reveals a contested intersection between state security and Australian migrants, which challenged the parameters of freedom of speech. Hayes' chapter reveals the ongoing, problematic relationship between Australia's 'national values' and its entanglement with the long-feared Asian 'Other'.

Part II, titled 'Intimate Violence', focuses on the legacies of violence that are wrought in close personal relationships. The first chapter, by Joy Damousi, investigates the forced removal of children from families overseas. It uses the analytical prisms of war, migration and trauma to investigate the child migrants who came to Australia following the Greek Civil War. As she notes, '[w] hile memories of wars in Australian history have of course been the subject of several studies, the impact of transnational migration on the memory and the psychological impact of those who experienced it await further consideration'. The transnational aspects of war, memory and intergenerational identity are at the core of her work. Damousi's chapter centres on personal narratives regarding motherhood and childhood, and the enduring legacies of parenting in conditions of war. Yet, rather than focus solely on an analysis of family life, the chapter focuses on the twin experiences of war and migration to situate the personal experiences of Australians in their global context.

Suzanne Rutland writes of the experiences of those who survived the Holocaust and subsequently migrated to Australia. The context for their movement was determined by the Australian government's determination to continue its control of new arrivals' ethnic and religious background through measures that discriminated against the Jewish refugees. Yet, Rutland reveals that the Jewish survivors drew on a number of transnational reciprocal relationships with like-minded others in the United States, Europe 
and Australia. As a consequence, the number of Jewish families in Australia grew markedly in the postwar era. Like Damousi, Rutland investigates the legacy of pre-migration violence on family relationships. At the heart of the Holocaust's impact was a sense of rupture and silence at the individual and family level. Rutland cites Ruth Wajnryb's comment that 'there was no past. The past was cordoned off, sealed out. There was a complete severance with what went before'. ${ }^{2}$ This inability to articulate the trauma gradually shifted into a search for a public language that could affirm and honour those killed, as well as establishing a public presence for the survivors to bear legitimate witness.

Robert Reynolds and Shirleene Robinson continue the exploration of bearing witness in their discussion of the impact of the HIV/AIDS epidemic on the gay community in Sydney. As with other chapters that consider the atomization caused by suffering, they focus on the emotional impact of the epidemic. The chapter explores how the 'death sentence' of acquiring HIV/ AIDS severed the individual from anticipated futures, binding them to the 'fading names and corpses of the otherwise forgotten dead'. ${ }^{3}$ The authors reveal the difficult search for a language of how to talk about the men's grief and shock, but also discuss the fracturing of communities under intense stress. Reynolds and Robinson reveal how the experiences of internal exile from friends and loved ones were compounded by the taboo surrounding the illness. Many actively sought to invoke the language of warfare as a means to situate their activism and resistance, honour the dead, and legitimate the epidemic in the national narrative.

The collection's final part, 'Sanctioned Violence', investigates violence that is known and condoned, frequently by the state. Martin Crotty's chapter investigates the Returned Sailors' and Soldiers' Imperial League of Australia, more commonly known as the RSL, and how it attained its high status and influence. He explores how the organization used violence to both threaten and cajole government. The men's experience of violence flowed from overseas into Australia, where they were able to use it to enhance a sense of public dominance. Their highly gendered campaigns challenged the state's legitimacy by drawing on their ability to express publicly their indignation and anger at alleged injustices. The threat of violence was used to attain government concessions for the men, but also to discriminate against political and ethnic 'Others'.

Richard Gehrmann's chapter details the lives of Australian service personnel in India. He analyses their response to violence in its literal sense, but also the violence wrought to people's dignity by extreme poverty. The Australians who bore witness to this poverty reflected on the construction of subalternity in terms of both race and gender, conveying their thoughts to 
friends and family back home. The Australians occupied a shifting position as white subjects within the British Empire, being at once complicit in the imperial project and distanced from the metropole. As Gehrmann reveals, their experience in India can be understood as one of a number of emerging contacts with Asian nationalism, helping to inform Australians' emerging sense of place, vulnerability and race in the region.

Andy Kaladelfos and Lisa Featherstone investigate race and gender in postwar Australia through a series of sex crime trials. Their chapter connects with a number of others in the collection, in its exploration of 'how the state negotiated culturally contested meanings over gender and violence'. By focusing on postwar migrants and refugees, the authors connect this negotiation with the postwar legacy of violence and trauma. Anglo-Australians couched their concerns in the language of threatened national virility 'at the hands of foreign sexual criminals', deploying heteronormativity at the heart of a discourse of whiteness. This racialization of crime, overlaid with the portrayal of gender-based violence, is at the core of their chapter (and connects similarly with a number of other chapters in the collection). They reveal how immigration status and cultural preconceptions have fundamentally limited people's access to justice throughout Australian history, and that this challenge continues in the present time.

Farida Fozdar examines Australia's contemporary migration policy and the restriction of asylum-seekers' rights as a form of passive violence. Her chapter assesses how a sense of crisis is created by the language of securitization and warfare, which surrounds Australia's public debate regarding asylum seekers. Her exploration of criminalization and race connects with other chapters, and has been an ongoing theme throughout Australian history. The current manifestation continues to affect perceptions of human rights and duties of care to vulnerable people. Fozdar, similarly to Briskman, uses Giorgio Agamben's exploration of the 'state of exception' to analyse the Australian government's response to asylum seekers. ${ }^{4}$ She does this within a context of the Global North, in which the 'off-shoring' of responsibilities is increasingly used to buffer states from mobile populations beyond their borders, and to deny safety to non-members of the nation state. Fozdar questions the state's right to deny such membership by force. The state's sovereign right to enact violence on others' bodies, and the role of the law within this, is at the heart of this chapter and of the entire collection.

Together, the volume's chapters provide an in-depth investigation into the experiences of violence in Australia. The collection focuses on one country to draw attention to changing experiences of violence, and to consistencies in how experiences of violence have been silenced and given voice over time. The chapters centre on questions of the role of the state, whiteness and masculinity 
in framing violence. They integrate a wide variety of approaches and case studies, all seeking to give voice to the experience of the marginalized and silenced. The findings shed light on the extent to which Australia's experience of violence connects with global debates, such as processes of colonialism and globalization. Rather than see Australia as exceptional and isolated, the collection asserts the global connections that have influenced how Australians make sense of violence. It asserts the responsibility of remembering, and the opportunities this presents to develop an inclusive and cohesive society.

\section{ROBERT MASON}

Robert Mason is lecturer in migration and security studies at Griffith University, Queensland. He is editor of a number of collections, including Cultures in Refuge: Seeking Sanctuary in Modern Australia (2012, with Anna Hayes) and Migration and Insecurity: Citizenship and Social Inclusion in a Transnational Era (2013, with Niklaus Steiner and Anna Hayes). His research focuses on emotion and the legacies of violence in both migration and heritage. He is particularly interested in Spanish- and Portuguese-speaking communities in Asia, Australia and North America.

\section{NOTES}

1. Klaus Neumann and Janna Thomson (eds), Historical Justice and Memory, Madison, WI, University of Wisconsin Press, 2015.

2. Ruth Wajnryb, The Silence: How Tragedy Shapes Talk, Sydney, Allen and Unwin, 2001, p. 6.

3. Sarah Schulman, The Gentrification of the Mind: Witness to a Lost Imagination, Berkeley, CA, University of California Press, 2012, p. 45.

4. G. Agamben, State of Exception, translated by K. Attell, Chicago, IL, University of Chicago Press, 2005.

\section{BIBLIOGRAPHY}

Agamben, G., State of Exception, translated by K. Attell, Chicago, IL, University of Chicago Press, 2005.

Neumann, Klaus, and Janna Thomson (eds), Historical Justice and Memory, Madison, WI, University of Wisconsin Press, 2015.

Schulman, Sarah, The Gentrification of the Mind: Witness to a Lost Imagination, Berkeley, CA, University of California Press, 2012.

Wajnryb, Ruth, The Silence: How Tragedy Shapes Talk, Sydney, Allen and Unwin, 2001. 